\title{
Religion and fertility ideals, intentions and behaviour: a comparative study of European countries
}

\author{
Dimiter Philipov and Caroline Berghammer*
}

\begin{abstract}
European demographers rarely study religion as a determinant of contemporary demographic behaviour. One reason could be the secularisation observed in European countries, implying that the effect of religiosity has been diminishing. This paper aims to show that religion can have an important impact on ideals, intentions and behaviour related to fertility.

First we discuss recent trends in religiosity. We base our ensuing hypotheses on three deliberations why religion may have a bearing on fertility: importance of religious teaching, effect of social capital and function of religion to decrease uncertainty.

Using FFS data we examine the influence of several measures of religiosity on the ideal number of children and intentions to have a second and third child, as well as on the expected and actual number of children. We find that all measures of religiosity are in general related to a higher ideal number of children, higher odds to intend another child and higher expected and actual number of children. Participation in religious services turns out to be slightly more salient than affiliation and self-assessed religiosity. We also discover that the effect of religion on ideals is more pronounced than its effect on intentions. Ideals stay further away from behaviour than intentions do and hence the influence of religion is intermediated by other social systems.
\end{abstract}

\footnotetext{
* Dimiter Philipov (author for correspondence), research group leader, Vienna Institute of Demography, Austrian Academy of Sciences, Wohllebengasse 12-14, 1040 Vienna, Austria. Email: dimiter.philipov@oeaw.ac.at

Caroline Berghammer, PhD student, Vienna Institute of Demography, Austrian Academy of Sciences, Vienna
} 


\section{Introduction}

Traditional religious teachings advocate life in a sound traditional family with many children and take an adverse stand to non-marital sex and thus to cohabitation. Yet the demographic changes in Europe during the recent decades include a drastic decline in fertility and the increase of non-traditional family forms, single-person households and non-marital births. The rise of these trends implies that religion may have lost its impact on demographic behaviour. In their influential article Lesthaeghe and Surkyn (1988) addressed this causal link. They discussed secularisation and individualisation as the "two most salient features" of the ideational shifts that have spread over Europe in the last few decades. They considered the rise in individualisation and personal autonomy as opening new perspectives and broader choices related to family formation and childbearing. Secularisation was a necessary condition for the rise in individualisation as it brought about a release of the norms and restrictions that originated in rules and rites set by the churches. As secularisation continues the Christian churches are less and less capable of influencing people's behaviour (van de Kaa 1999: 42) and religion can, as a consequence, be disregarded.

Seemingly the secularisation thesis has found a firm ground among European demographers, as far as demographic research indicates. Indeed, religion if not simply missing in studies of issues related to family formation, has typically been included in demographic models in the form of independent variables whose explanatory power is restricted to being 'controlled for'.

The general negligence of religion is reflected in demographic surveys. If not entirely omitted usually only a few questions on religiosity are included. The Fertility and Family Surveys (FFS), conducted during the 1990s, contain four questions, on self-assessed religiosity, religious affiliation, church attendance and importance of God. In the successive study, the Gender and Generations Surveys (GGS), the questions on self-assessed religiosity and importance of God were dropped. The questionnaire for the second wave of the GGS does not comprise any question on religion at all.

Detailed studies on the effect that religion might have on the occurrence or timing of family-related events and fertility are rare, and more likely to be found in national demographic studies of countries where religion is particularly persuasive, such as Spain (Branas-Garza and Neuman 2006; Adsera 2006a) or Italy (Caltabiano et al. 2006). Most recently the following studies took up the question on the relation between religion and fertility.

Adsera (2006a) analysed two Spanish fertility surveys dating from 1985 and 1999 to compare the impact of religiosity in older and younger cohorts. While her findings do not confirm any differences in family size between practicing and non-practicing Catholics in the older cohorts, they do for the younger ones. Family size of non-practicing Catholics is lower and reaches levels similar to the non-affiliated. 
Frejka and Westoff (2006) investigate the importance of religiosity in the transatlantic fertility differences. For European countries they state that the risk of having two or more children is associated with different religious measures in different regions of Europe. In southern Europe church attendance significantly determines progression to higher order births while the measure of the importance of religion is most relevant in western Europe. The results for religious affiliation are mixed.

Kaufmann (e.g., 2006) tackles the question if the share of religious people in European populations will rise due to their higher fertility and to immigration from countries where religion is prevalent or, alternatively, if religious apostasy will counterbalance these effects. He concludes that the portion of religious people will increase due to migration and fertility differentials.

Adsera's study on the association between religion and ideal number of children in 13 developed countries (2006b) is especially relevant for the work at hand. We extend her analysis examining fertility ideals by additionally shedding light on fertility intentions and behaviour. Moreover, next to regarding religious affiliation and frequency of attending religious services we also employ selfassessed religiosity and importance of God as measures for subjective religiosity.

Using ISSP data Adsera showed that weekly church attendance relates to a higher ideal number of children, for women more distinctively so than for men. In countries where one religious organisation holds a monopoly, religious affiliation as such is not reflected by differential fertility ideals conversely to pluralistic societies where both, affiliation and participation, matter (p. 279). Pooling data for all countries she reports that the ideal number of children is highest for conservative Protestants, followed by Catholics, those with other religion and mainline Protestants. The ideal family size is lowest for the non-affiliated (p. 281). Conducting the analysis separately for different cohorts reveals that the importance of affiliation for fertility ideals diminishes with successive cohorts. This observation is stronger for women than for men where belonging to a certain denomination still makes a significant difference. In accordance with the hypothesis that the decreasing influence of religious organisations leads to increased disparity between regular and non-regular attendees, Adsera finds that church attendance is a strong predictor of ideal family size for younger generations, especially for women (p. 282-283).

Unlike in Europe, research in the USA on the interrelations between religion and demographic events related to family formation and fertility reports detailed findings. Lehrer (2004) and McQuillan (2004) provide comprehensive reviews. However, the concept of religion in the USA differs significantly from that in Europe (Frejka and Westoff 2006): religious affiliation and religiosity in the USA are considerably higher as compared to those in most European countries, and the process of secularisation has not been dominant in this country. While in many European countries religious institutions take monopolistic or duopolistic positions, the religious structure in the United States is marked by the existence of 
a large variety of denominations. Thus a straightforward transfer of US-related findings to European countries without adequate testing or replication can be misleading.

Modifying the secularisation hypothesis, recent sociological research on religion in Europe indicates, however, that its importance for societal life should not be underestimated. Religion experienced a significant transformation along with the overall ideational shifts. Recent decades have witnessed the emergence of notions like 'post-modern' religion and 'believing without belonging', used to denote new trends in the development of religiosity. Although these are topics of heated debates they indicate that religion and religiosity should not be trivialised in studies aiming to understand aspects of contemporary societal life. So are demographers missing an important field of research? Lesthaeghe and Surkyn (1988: 9) noted that the role of religion is neither exhausted nor can it be neglected in the study of contemporary fertility and family change. Nearly 20 years later we have no reason to disregard this warning.

The study at hand intends to show that contemporary interrelations between religion and fertility ideals, intentions and behaviour in Europe are significant after all and deserve more attention in demographic research. There are three questions to the analysis that follows:

1) Given the erosion of religiosity during the last decades, is religion still an important factor for fertility in Europe?

2) Through which channels can we assume religiosity to affect fertility?

3) What empirical associations can we attest between religion and fertility ideals, intentions and behaviour?

We first give an overview of the current perspectives about changes in religiosity and its persistent importance which we see as being significant for demographers. Next we formulate some conjectures on aspects of the relations between fertility and religion. We further discuss the measurement of religion and continue with an empirical comparative study using the FFS data. We examine the association between religion and religiosity on the one hand, and ideal number of children, intentions to have a second and third child, expected and actual number of children, on the other. Since we provide a comparative study of 18 European countries it is beyond the scope of this paper to concentrate on the explanation of results of single countries. Our empirical data are not suitable for the study of any other religious denominations but Christianity because of the small number of observations. For this reason this paper focuses only on issues referring to Christianity. 


\section{Recent trends in religion}

Secularisation is a trend that has run for centuries in western Europe. Its roots may be found in the Renaissance with the revival of humanism. Prominent philosophers and sociologists like Hume, Marx and Weber envisaged the disappearance of religion as a result of modernisation of society; scientific, technical and economic progress as well as advancement in education. A significant decline in religion, if not disappearance, is a position shared by numerous researchers both in the past and at present.

Secularisation is a multifold process that at the macro level applies to society as a whole, and at the micro level to individuals. First, it denotes a decline in the influence of religion on societal life as institutions of law, administration, education, medicine, commerce and so on become separated from church control (McQuillan 2004: 32-33). Second, on the micro level, individuals withdraw from their religious communities as they cease to take part in regular services as well as in religious rites that frame life course transitions and the like. Secularisation on the level of the individual also encompasses the decline of religious beliefs and private religious practices.

During the recent decades secularisation has been a topic of debate among researchers of sociology of religion. Where Europe is concerned, the decline in the influence of the churches is rarely disputed, unlike the decline in religiosity not bound to an institution. While some authors indicate the stability or even rise in religiosity in Europe, others deny similar conclusions; we present the views of both sides briefly.

A ground-breaking article was contributed by Davie (1990) who found an increase in 'believing without belonging' (BWB) in a study of changes in religiosity in Great Britain. The quoted expression was used to denote persons who have religious beliefs and who feel they are religious, but are not attached to a church and do not strictly adhere to church rites, rules and practices. The main argument is that "Europeans continue to believe in God and to have religious (or at least 'spiritual') sensibilities: the proportion of believers is high and has changed little in recent years" (Voas and Crockett 2005: 12). Several studies have provided empirical support. For example, Stark et al. (2005) propose that "unchurched religion and spirituality" are on the rise particularly among younger cohorts in Sweden and have been persisting in Japan for a long time. Lambert (2004), using the three waves of the EVS, concludes that the data of the 1999/2000 wave suggest a 'Christian renewal' and 'believing without belonging', particularly among respondents aged 18-29.

Other studies refute the perception that personal beliefs and practices remain stable or show an increasing trend even if institutionalised religiosity decreases. Based on data that cover the 1990s and others collected between 1983 and 2003 Voas and Crockett (2005) find that the thesis about a rise of BWB in Great Britain does not hold (at least for distinct Christian beliefs as opposed to vague beliefs 
and spiritual sensibilities). Halman and Draulans (2006), working with EVS data from 1999/2000, find that religiosity is lower in countries where the GDP is higher and conclude that modernisation of society correlates with a decrease in religiosity, which is in line with the secularisation thesis. However, they did not find statistically significant differences in the level of religiosity between materialists and post-materialists (p. 277).

Some scholars argue that even if the figures for belonging to a certain religion or those that display religious belief show an increase, this can not necessarily be explained by a rise in religiosity. Voas and Bruce (2004) provide an interesting example by comparing the 2001 census in Britain with the British Social Attitudes survey. The former reports $72 \%$ Christians in England and Wales, a proportion that is considerably higher than that found in the British Social Attitudes survey. They explain the mismatch by seeing the census results "to represent increasing anxiety about national identity rather than increasing commitment to the Christian faith" (p. 28).

It is not the interest of this paper to provide support for one or the other side, i.e., for research that challenges the secularisation hypothesis or for advocates of the continuing downward trend even pertaining to private beliefs and practices, but we can conclude that religion is a matter of lively debates and as such an important topic to be addressed in contemporary demographic studies.

\section{Religion and fertility: hypotheses}

The complex relations that exist between religiosity and fertility have given rise to diverse approaches and classifications on the channels by which they are linked.

For this reason we propose a brief discussion of three mechanisms that are likely to be relevant for the explanation of the impact of religion and religiosity on contemporary fertility and family change in the European countries: the impact of religious teachings, the impact of social capital and the impact of subjective wellbeing and uncertainty.

Since most religions hold views on issues related to family, children and the proximate determinants of fertility it stands to reason to employ them as a starting point. The importance of religious teachings for fertility has achieved extensive attention among sociologists of religion and demographers. It is presented here in a concise form.

Within Christianity, in the Catholic church contraception and abortion in particular have continually been at the centre of hot debates. Marriage and having children are encouraged while non-marital sex and non-marital births are opposed. The Catholic church holds explicit views on these matters, which are given out to their adherents as prescriptions. Followers of the church are expected to observe these rules. To a lesser extend, this pattern has been characteristic for the Orthodox churches. In mainline Protestantism no such explicit rules and 
prohibitions exist. We do not address differences between the Christian denominations in detail; this important topic requires comparative discussions which are out of the scope of the present paper. McQuillan (2004) provides a systematic background on the impact of religion on fertility where differentials by affiliation are presented in detail.

Already Goldscheider (1971) provided some criticism of the perception that the existence of a 'particularised theology', i.e., explicit teaching on fertility and related issues, should necessarily entail accordant behaviour. McQuillan, however, warns to reject considerations about any specific religious teaching altogether. He claims that "religious teachings touching on demographic issues form an important part of a religious world-view, and are a necessary, though not sufficient, condition for the formation and continuation of a distinctive demographic pattern" (1999: 8). In line with Goldscheider he argues that such a world-view goes beyond specific instructions on fertility, but more generally includes the perceptions of a religious organisation, notably on gender relations and parent-child relationships (McQuillan 1999: 10 and 2004: 26).

Moreover, religious teachings can have an indirect impact on fertility exercised through social norms and values. Christian teaching has permeated European societies for centuries. Long-standing religious views have been the basis for the rise and spread of relevant social norms and values related to family formation and fertility. The non-acceptance of non-marital cohabitation and nonmarital births in traditional societies may serve as examples. Those and similar norms and values exercised an effect regardless of whether the decision-makers were religious or non-religious individuals. These values have been integrated as a solid part of the cultural system of the society and as such have their place in the basis of society's legal system and in the practice of state institutions.

Recent demographic trends, particularly those that constitute the second demographic transition, indicate that the discussion exposed in the preceding paragraph relates to a society that can be characterised with traditional demographic behaviour. On the level of the wider society churches have lost their influence on other societal systems like the state and thus their ability to shape social norms and values.

Yet, on the level of the individual we assume that those who indicate their belonging to a certain church against a vigorous countertrend should show a particular behaviour, presumably also with respect to childbearing.

H1: Fertility ideals, expected and actual number of children are higher and intentions to have another child are more prevalent among those who are affiliated, most notably with churches characterised by strong pronatalist and pro-family teaching, as compared to the non-affiliated.

The second approach relates to the associations between religion and social capital as well as to the effect of social capital on fertility. The impact of religion on social capital has been widely noted (Davie 2002; Agadjanian 2001; Waite and 
Lehrer 2003; Lehrer 2004; Iannaccone $1990^{1}$ ). Waite and Lehrer (2003) for example discuss the influence of parents' religion on their children's social capital; the latter rises because of the social ties existing among members of a religious group. In general, religious persons may feel attached to a social group that includes individuals who share similar values and beliefs. They are likely to meet at church services or at other occasions and maintain and intensify friendly contacts. Religious organisations promote the formation of social networks.

Just as in secular social networks three types of support are exchanged between the church members: emotional, tangible and informational support. In addition, spiritual support is exemplary for religious settings (Krause et al. 2001: 638-639). Social support, received in church context from co-religionists or clergy is discussed in the extensive literature on religious coping as a kind of coping strategy (e.g. Pargament et al. 2000). Taylor and Chatters showed that church attendance, church membership and subjective religiosity are positively and significantly associated with the probability of receiving support (Taylor and Chatters 1988). More specifically, previous studies have demonstrated, for example, that membership in an informal church network increases the likelihood to receive advice and encouragement as well as gifts and help with home maintenance and running errands (Chatters et al. 2002; Ellison and George 1994). Secondly, religious networks are characterised by the existence of shared norms and values, like a high appraisal of children and marriage. These views are constantly maintained through communication with others and religious texts and as such held plausible against competing ones (Berger 1969). As a consequence, high fertility ideals and intentions become more likely, and so does having children itself. In turn, when a behavioural model is set, especially by people who are held in high esteem, other couples are compelled to follow the example. The case of social learning might be complemented with social pressure to comply with the collective behaviour.

Several demographic studies have examined the association between social capital and fertility and family formation events. The social capital component in social interactions can be noted in two ways. First, having children brings about an increase in social capital, as noted by Schoen et al. (1997) because close relatives and friends may feel attached to the new family member and provide support for the enlarged family. Besides, a new baby increases the family's social network with families that are in a similar status because of the commonalities in child care. Second, social interactions may be exercised in the form of help and support exchanged among social network members (Buehler and Philipov 2005). Social network members may provide important information, for example for finding a new (or better) job, they can lend money when necessary, help with repairs and reconstructions in the home, or provide easy access to babysitting. Help and support within the social network usually flow without a requirement for reciprocity (i.e., receiving help does not necessarily mean that it must be

${ }^{1}$ Iannaccone (1990) discusses human capital-related friendships which we refer to as social capital. 
returned), or reciprocity can be impersonal (i.e., giving help to any other member of the social network, and when help is needed it is not expected only from the person to whom help was previously given, but from any network member). Buehler and Philipov (2005) defined this form of social capital as social networks-based social capital. It is of significance in taking decisions about having children because it may relieve the impact of diverse factors that may bring about negative consequences when having a child.

The higher a person's social capital, the higher the likelihood that this person will have intentions for having a child. Schoen et al. (1997) provide empirical support for the USA, Buehler and Philipov (2005) for Bulgaria and Philipov et al. (2006) for Bulgaria and Hungary. It is of no difference whether one wants a child in order to increase one's personal social capital, as Schoen et al. (1997) argue, or whether one wants a child because one's social capital is already high, as Buehler and Philipov (2005) discuss.

To sum up, religiosity and social capital are positively linked, and the latter is associated with fertility intentions, and possibly fertility decisions. Here, religiosity mainly refers to organised religions as these are most capable of providing an adequate framing. Church attendance is not only a proxy for the access to social capital but also for the frequency of exposure to churchly teaching and to people who behave accordingly. Transcending the belonging to a certain denomination, which can be solely nominal, it implies active participation. We therefore expect attendance of church services to be a more decisive determinant than religious affiliation.

H2: Fertility ideals, intentions, expected and actual number of children are positively associated with church attendance.

H3: Church attendance is a stronger predictor for fertility than religious affiliation.

Thirdly, a number of studies confirm the positive effect of religiosity on psychological wellbeing and uncertainty. This link goes beyond organised religiosity and comprises 'believing without belonging' as well.

The Bible explicitly highlights the role of God as a defender, comforter and supporter of humans when needed (e.g., Ps 3; Mt 5:12). Followers of religious teachings are advised to rely on God when they need his support. Their belief in God helps them to cope with adverse life events and stressful situations. Also, religious practices are beneficial in establishing a relation with a higher power. Rites of passage, such as baptism or marriage, which exist in many religions, are deliberately located at transitory points in life that might imply uncertainty and unpredictability.

Moreover, even though the orientation of the believers towards afterlife has decreased markedly some believers are apt to downsize the effect of troubles and tribulations in earthly life. Utility of afterlife for them outweighs disutility in earthly life. 
An abundant literature supports the positive effect of religiosity on subjective wellbeing and coping. We give two references that are of interest to demographers. Clark and Lelkes (2005) use the European Social Surveys to analyse the role of religion in "buffering the well-being impact of stressful life events". They find that religious persons have a higher level of subjective wellbeing and are more satisfied with life; for example they experience a lower level of stress from unemployment or from a divorce. Lehrer (2004: 720) touches the issue in a theoretical framework.

Religiosity also positively affects the subjective wellbeing and coping through participation in religious groups where one can find support when needed. This topic relates to the one discussed above about the significance of social capital.

The effect of religiosity on uncertainty is a specific case of the effect of religiosity on subjective wellbeing and coping. Uncertainty relates to events expected in the future. The larger the uncertainty, the more likely are individuals to postpone or reject events that can happen to bear negative outcomes. This link is particularly strong when the events are irreversible and crucial to one's life. Having a child qualifies as an event of this type that can bring about less desirable outcomes, such as losing one's job or worsening living conditions. In such situations religious persons will rely on support by the supernatural power and, if belonging to a church network, on the help of others, hence the impact of uncertainty on their personal decision-making can be less pronounced.

The influence of the subjective wellbeing and of uncertainty on fertility is a relatively new topic of research in demography. Recently Philipov et al. (2006) indicated that a higher level of subjective wellbeing correlates positively with the intentions to have a(nother) child in Bulgaria and Hungary. The importance of economic uncertainty has been studied for a number of European countries. Mills and Blossfeld (2005) have discussed different forms of economic uncertainty, embedded in globalisation, at length (p. 18-19). They and others have found that postponement or rejection of life events such as marriage and having a child are reactions to increased uncertainty (Adsera 2005; Kohler et al. 2002).

While uncertainty has been considered in relation with religion and childbearing separately, as revealed by the preceding discussion, the concept is rarely to be found in studies dealing with the association between religion and fertility. This is unfortunate, also because in addition to being crucial for organised forms of religiosity, the function of religion to decrease uncertainty is an essential factor for people who have private beliefs and follow private practices without adhering to an institutionalised religion. However, they are also likely to share creeds with the traditional religions.

H4: Self-assessed religiosity and importance of God are positively related to ideals, intentions and expected and actual number of children.

Although so far we have derived our hypotheses from one of the aspects at a time, all of them remain valid for one religious measure. For example, the affiliated are more likely to attend religious services than the non-affiliated and thus are more 
prone to be exposed to religious teaching, form part of religious social networks and show less uncertainty due to the reasons exhibited above.

Lastly, we present an assumption about the relation between ideals, intentions and behaviour using the theory of planned behaviour, proposed by Ajzen and Fishbein (Ajzen 1991). According to this theory fertility intentions are a proximate determinant of behaviour (i.e., of births). Intentions are formed under the influence of a person's attitudes towards the behaviour, subjective norms related to the behaviour, and the perceived control that the person can exercise on the behaviour. An impersonalised ideal number of children is a value and values shape the attitudes and subjective norms and hence lie further away from behaviour as compared to intentions. Therefore, we can deduce that the impact of religion is weaker on intentions than on ideals because the latter stay further away from behaviour than intentions and are therefore not subject to constraints such as financial limitations or difficulties in finding a partner. This would mean that the expected strong impact of religion on ideals loosens during the process of construction of intentions along with their direct precedents such as personal attitudes, subjective norms related to the behaviour, and personal control over the behaviour. The expected number of children of childless women can be considered as a broader, more vague intention than that for a specific parity. Due to a similar, but more concrete rationale we expect religiosity to exert a stronger influence on intentions than on behaviour.

\section{H5: Measures of religiosity are more strongly associated with ideals than with intentions, and again less strongly with behaviour.}

Reverse causality is another dimension in the background of the relations between religion and fertility. It can arise because demographic events are contingent situations in life. For example, it may happen that the birth of a child alters the priorities in life and stimulates thoughts about a meaning in life. Parents might as a consequence be more inclined to turn to religious teachings. Also, they may become more religious after the birth of their child because they may get attached to a social group of parents with young children run by a church (to name only two possible reasons). Hence a birth may increase religiosity. Reverse causality may arise also where fertility intentions are considered: for example when a couple wants to have a child but the expected pregnancy does not come. It is unlikely to expect reverse causality where ideal number of children is considered. 


\section{Data and methods}

\subsection{Data and measurement of religion}

We use the data of the Fertility and Family Surveys (FFS) for European countries where at least one question on religion is included in the national questionnaire. No such question was asked in France. The FFS questionnaire includes the following questions that refer to religion (answers "don't know" are skipped):

1. (Number Q916 in the original questionnaire): Are you religious?

Answers: Yes, somewhat, no

2. (Q917: asked to those who answered with "yes" or "somewhat" to the above question): Which religion do you adhere to?

Answers: Catholic; Protestant; Christian orthodox; Freethinking; Jewish; Islamic; Other

3. (Q918): How often do you attend religious services (apart from weddings, funerals, baptisms and the like)?

Answers: More than once a week; once a week; about once a month: only at official holidays; once a year; (practically) never

4. (Q919): How important is God in your life?

Answers: Very important; rather important; neither unimportant nor important; rather unimportant; totally unimportant

Table 1 informs about the year of survey, the sample size used in our estimates and the questions asked in each studied country.

The first question measures religiosity, independently of whether it is church religiosity or 'believing without belonging'. The inclusion of the term 'religion' in the statement, however, induces the reference to an institutionalised religion and it is ambiguous and context dependent if people who hold fuzzy, non-Christian beliefs or have spiritual sensibilities would indicate to be religious.

The second FFS question asks for the affiliation. It is a classic one; research on religion in the US frequently centres on denomination only. However in Europe this question can be ambiguous because it may relate to "natal belonging" or national or cultural identity (Voas and Bruce 2004; Day 2006). A close interrelation between religion and nation has been noted in several cases, e.g., an identification with the Scandinavian state churches that does not involve church participation (Stark and Iannaccone 1994: 237-238) A survey in Bulgaria carried out in 2002 with a sample of 10,000 men and women aged up to 35 showed that $90 \%$ of all ethnic Bulgarians in the sample adhered to Bulgarian Orthodox and $44 \%$ of the latter stated they are not religious. Orthodoxy is an important component of the Bulgarian culture, and $44 \%$ of the respondents obviously understood the question as asking about culture, not about religion. The ambiguity in the FFS questionnaire is likely to be restricted though, since the question is 
asked only to respondents who have stated in the preceding question that they are religious.

Table 1:

Year of survey, sample size and religion-related questions used, by country

\begin{tabular}{lcccccc}
\hline & $\begin{array}{c}\text { Year } \\
\text { of } \\
\text { survey }\end{array}$ & $\begin{array}{c}\text { Sample size } \\
\text { (women } \\
\text { below age 40) }\end{array}$ & $\begin{array}{c}\text { Are you } \\
\text { religious? }\end{array}$ & $\begin{array}{c}\text { Which religion } \\
\text { do you adhere } \\
\text { to? }\end{array}$ & $\begin{array}{c}\text { How often do } \\
\text { you attend } \\
\text { religious } \\
\text { services? }\end{array}$ & $\begin{array}{c}\text { How } \\
\text { important } \\
\text { is God in } \\
\text { your life? }\end{array}$ \\
\hline Austria & $1995-96$ & 2843 & $\mathrm{x}$ & $\mathrm{x}$ & & \\
Belgium (Flanders) & $1991-92$ & 3088 & & $\mathrm{x}$ & & $\mathrm{x}$ \\
Bulgaria & 1997 & 1834 & $\mathrm{x}$ & $\mathrm{x}$ & $\mathrm{x}$ & \\
Czech Rep. & 1997 & 1419 & $\mathrm{x}$ & & $\mathrm{x}$ & $\mathrm{x}$ \\
Estonia & 1994 & 1228 & $\mathrm{x}$ & $\mathrm{x}$ & & \\
Finland & $1989-90$ & 2637 & $\mathrm{x}$ & & $\mathrm{x}$ & \\
Germany, East & 1992 & 2912 & $\mathrm{x}$ & $\mathrm{x}$ & $\mathrm{x}$ & $\mathrm{x}$ \\
Germany, West & 1992 & 2945 & $\mathrm{x}$ & $\mathrm{x}$ & $\mathrm{x}$ & $\mathrm{x}$ \\
Greece & 1999 & 2145 & $\mathrm{x}$ & $\mathrm{x}$ & $\mathrm{x}$ & $\mathrm{x}$ \\
Hungary & $1992-93$ & 3193 & $\mathrm{x}$ & $\mathrm{x}$ & $\mathrm{x}$ & $\mathrm{x}$ \\
Italy & $1995-96$ & 3353 & $\mathrm{x}$ & $\mathrm{x}$ & $\mathrm{x}$ & \\
Latvia & 1995 & 1817 & $\mathrm{x}$ & $\mathrm{x}$ & $\mathrm{x}$ & $\mathrm{x}$ \\
Lithuania & $1994-95$ & 2205 & $\mathrm{x}$ & $\mathrm{x}$ & & \\
Norway & $1988-89$ & 3472 & & & $\mathrm{x}$ & \\
Poland & 1991 & 2957 & $\mathrm{x}$ & $\mathrm{x}$ & $\mathrm{x}$ & \\
Slovenia & $1994-95$ & 2185 & $\mathrm{x}$ & $\mathrm{x}$ & $\mathrm{x}$ & $\mathrm{x}$ \\
Spain & 1995 & 3056 & $\mathrm{x}$ & $\mathrm{x}$ & $\mathrm{x}$ & $\mathrm{x}$ \\
Sweden & $1992-93$ & 2651 & & & $\mathrm{x}$ & \\
Switzerland & $1994-95$ & 2503 & $\mathrm{x}$ & $\mathrm{x}$ & $\mathrm{x}$ & $\mathrm{x}$ \\
\hline
\end{tabular}

The third question measures religious practice. It can also be ambiguous where fertility is studied, in that a visit to a church can be, for example, either because of the wish to participate in the ceremony and/or to meet members of a social network. Moreover, parents of young children may decrease their churchgoing practices because they need more time to look after the child. We do not have an indication about the size of these ambiguities. Furthermore we need to take into account that church attendance is of different importance in the different denominations. While it is very salient for the Orthodox and prescribed for Catholics there is less accordant concern for the mainline Protestants. We need to be aware that Muslim women, who are only studied in Bulgaria, generally attend collective prayers in the Mosque less often than men do. Hence other religious measures such as the frequency of prayer would suit their religious practices more adequately.

The fourth question measures the degree of religiosity of persons who accept the existence of God.

The measurement of religion and its operationalisation is an issue of considerable dispute among sociologists of religion. Huber (2003) presents a 
detailed discussion. He compared the question on self-assessed religiosity with five answering categories with a scale of 10 questions representing an operationalisation of 5 dimensions of religion, using interview results from 871 university students (Huber 2003: 218-219). He found that the correlation between the one-item measure and the scale was close to 0.8 . This high correlation coefficient implies that a single question is convenient for the measurement of religiosity. It is hard to expect that detailed measures of religion can be included in demographic surveys, and demographers may rely on simplified measures based on findings like this one.

Figures 1a-c and Table 2 show the observed distributions of responses. Female respondents below the age of 40 are considered only. Figure 1a displays the distribution of answers to the question measuring self-assessed religiosity. It reveals that in half of the depicted countries the percentage of religious persons exceeds $50 \%$, while in the other half, mostly ex-socialist countries, less than $50 \%$ declare themselves religious. The difference between ex-West Germany where about $60 \%$ declared to be at least somewhat religious and former East Germany where only $20 \%$ did so is in fact noteworthy. The percentage of non-religious or only somewhat religious respondents in Poland is very small but due to the large sample size the number of these respondents suits the use of statistical models.

Figure 1a:

Answers to the question "Are you religious?", women below age 40, in per cent

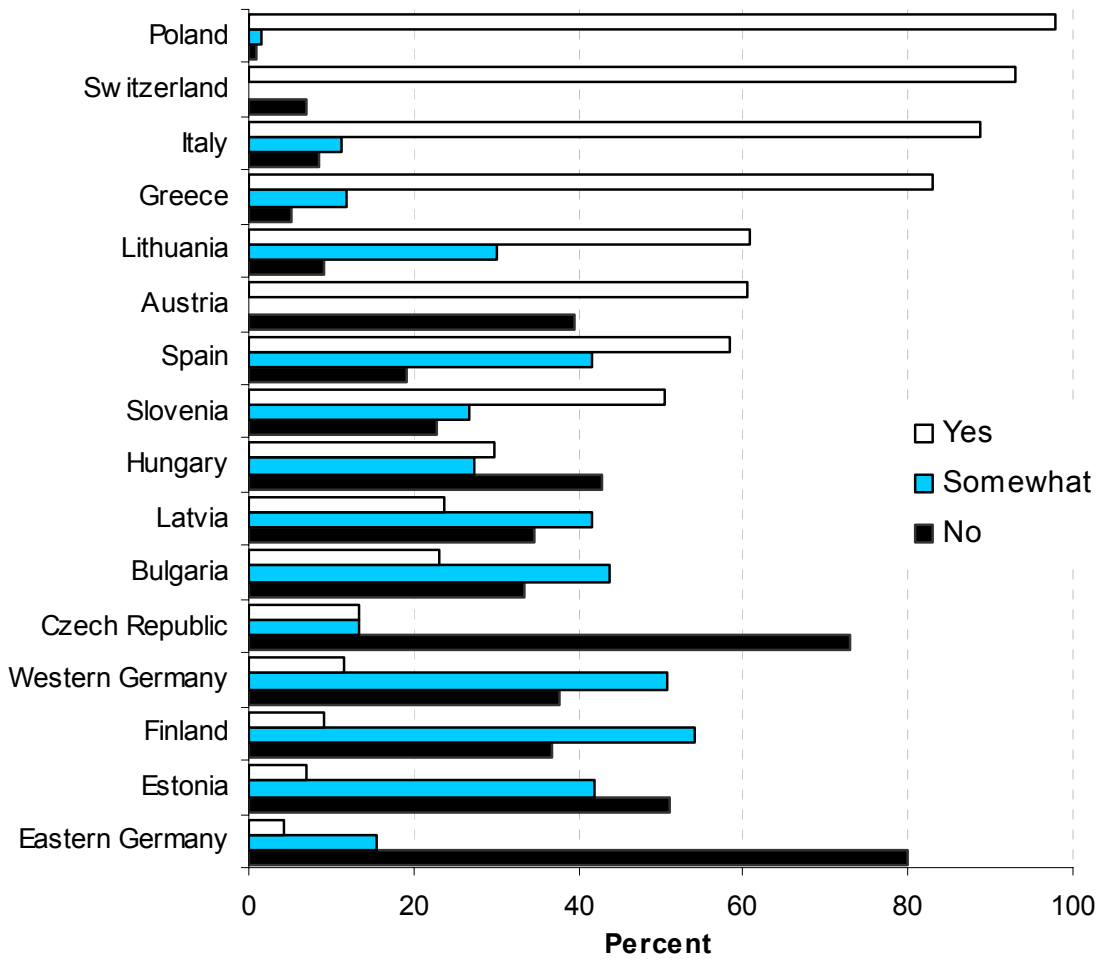


Figure 1b:

Proportion going to church once a month or more frequently, women below age 40, in per cent

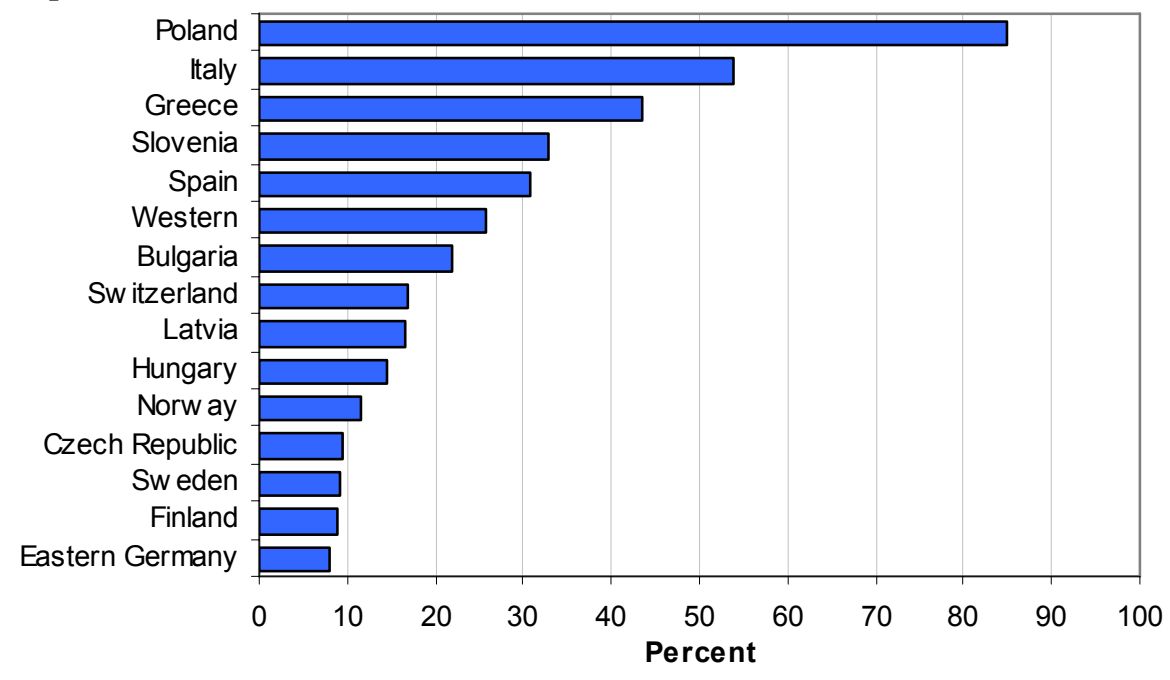

Figure 1c:

Proportion for whom God is very important or important, women below age 40, in per cent

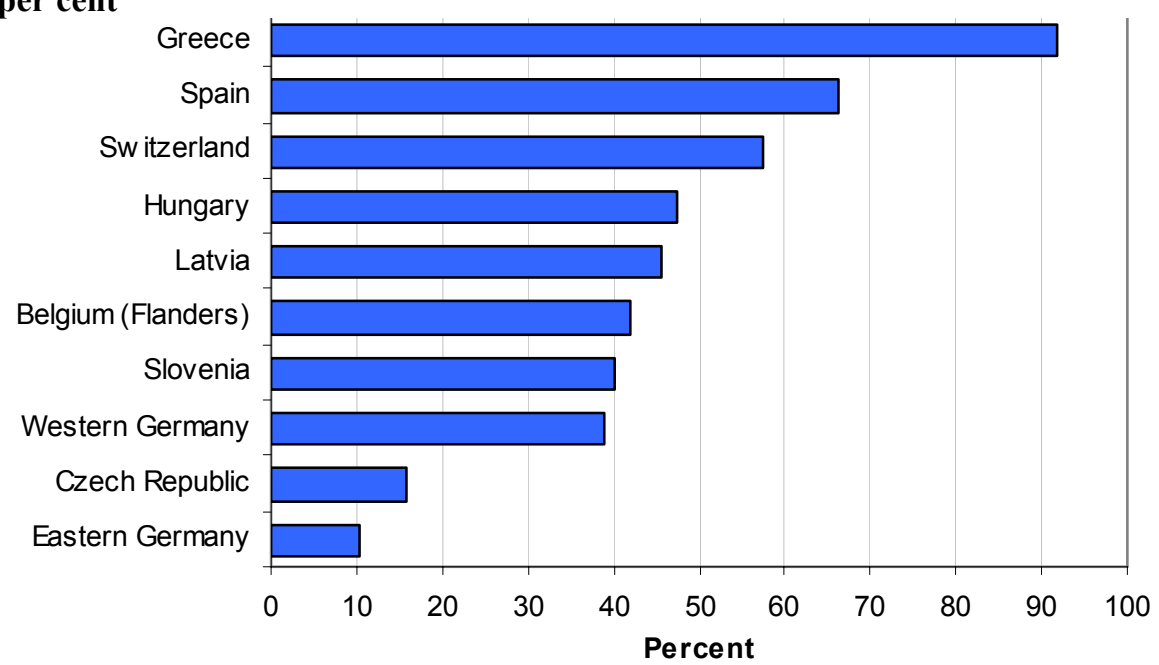

Note: In Figure 1a the countries are presented in a descending order according to the percentage for "Yes" answers. Data are weighed.

Figure $1 \mathrm{~b}$ gives the percentage of respondents who attend religious services once a month or more frequently. Poland and Italy, known for high religiosity of their population, indeed exhibit the highest levels of church attendance. At the other extreme are the Nordic countries and several ex-socialist countries including 
the eastern provinces of Germany. Figure 1c presents the proportion for whom God is very important or important. Belgium (Flanders) for which no numbers have been displayed previously is approximately found in the middle of the range.

Table 2 gives the distribution by religious denomination. The category 'freethinker' was frequently mixed with other denominations in country-specific questionnaires, therefore it is unfit for international comparisons. Hence, given we can interpret this category as 'believing without belonging', we cannot effectively include this status in our study as it was done by Halman and Draulans (2006). We recall that the FFS surveys were carried out during the 1990s, most of them in the beginning of the decade, and two at the end of the 1980s; at the time of its organisation the debate around BWB and unchurched religion was yet to come.

Within-country comparisons between adherents to Catholicism and Protestantism are effective in some countries, predominantly western Germany, Switzerland and Latvia. The Orthodox Church prevails in Greece and in Bulgaria; about $8 \%$ of the respondents in the latter country adhere to Islam. This is the only country where the number of Muslims is presented satisfactorily from a statistical point of view.

Table 2:

Distribution by Catholics, Protestants, Orthodox, Freethinkers and non-affiliated, women below age 40, in per cent (weighted)

\begin{tabular}{lccccc}
\hline & Catholic & Protestant & Orthodox & Freethinker & Non-affiliated \\
\hline Austria & 53 & 3 & 0 & 4 & 40 \\
Belgium (Flanders) & 82 & 0 & 0 & 7 & 11 \\
Bulgaria & 0 & 0 & 57 & 1 & 34 \\
East Germany & 4 & 13 & 0 & 0 & 83 \\
Estonia & 1 & 40 & 5 & 0 & 54 \\
Greece & 0 & 0 & 94 & 0 & 5 \\
Hungary & 46 & 9 & 0 & 0 & 45 \\
Italy & 91 & 1 & 0 & 0 & 9 \\
Latvia & 21 & 19 & 23 & 0 & 37 \\
Lithuania & 86 & 1 & 3 & 0 & 9 \\
Poland & 98 & 1 & 0 & 0 & 1 \\
Slovenia & 72 & 1 & 3 & 1 & 24 \\
Spain & 77 & 0 & 0 & 3 & 19 \\
Switzerland & 53 & 38 & 1 & 0 & 7 \\
West Germany & 34 & 27 & 0 & 0 & 39 \\
\hline
\end{tabular}

Note: The proportion of non-affiliated respondents was estimated from the question on self-assessed religiosity.

\subsection{Interpreting associations between religion and fertility}

The previous discussion indicated that there exist two-way interrelations between religion and fertility behaviour. The operationalisation and measurement of religion in the FFS surveys excludes the possibilities for their analyses, however. 
Religion is measured at the time of survey while the reported births took place before the survey. So the use of statistical models relates to the measurement of association rather than causality. In order to interpret associations just as well as causalities we would need additional information that is not directly available in the data.

A number of studies highlight changes of religiosity in a population. These changes can occur by age, by cohorts or by periods. There is a large debate in the literature on what effect is the dominating one. Some research in the US indicates that young adults' religiosity increases with age. Argue et al. (1999) report that religiosity increases faster in the age interval 18-30. Stolzenberg et al. (1995) found that family formation events have a significant effect for the increase of church membership by age 32. However, Chaves (1991) who studied Protestant church attendance reports a significance of cohort effects along with the age effects, and Miller and Nakamura (1996) in their study of church attendance patterns found that age effects are offset by intergenerational change. Studies referring to the UK indicate that cohort effects are the dominating ones. Crockett and Voas (2006) state that "Britons do not get more religious as they get older", and Voas and Crockett (2005) find that the decline in religiosity is generational. They consider religious affiliation, attendance and belief. An analysis by Tiley (2003) indicates that family formation does not cause greater religiosity and that generational differences cause both age differentials and the overall decline in church attendance in Britain. Hamberg (1991), however, using panel data for Sweden from 1955 and 1970 found the decline in religious beliefs to be due both to cohort and age effects. We conclude this review with Lesthaeghe and Surkyn (1988) who argue that secularisation develops through the sequence of cohorts.

The studies mentioned above usually indicate that change in religiosity by age refers mainly to a change in its intensity when measured by religious practices. A young mother or father may start visiting church services more frequently, for example to enable the child to make similar positive church related childhood experiences like she or he had; inversely the parent can reduce frequency of church attendance because she or he needs to devote more time to the baby. However, we have found no reports of a change in religiosity by age when measurement of religiosity is dichotomised. That is, it might rarely happen that a demographic event invokes a change from the status of being religious, independent of the degree of religiosity, to the status of being non-religious, or vice-versa. More frequently, changes can occur between various degrees of religiosity, such as being religious or somewhat religious.

The problem of association and causality is considerably different in the case of intentions to have a second or third child as well as the ideal number of children. Although both are measured at the time of survey, like religiosity, there may also be reverse causality. However, it is hard to imagine that there are many situations where intentions to have a second or third child or views about the ideal number of children may influence religiosity. In the case of intentions, one can 
speculate that religiosity may change after the couple has been waiting for a further child for too long. We were able to control for this effect by including a variable that describes the interval since the last birth.

It is thus convenient to assume that reverse causality does not have a significant effect on model results. We do not take this statement for granted unless it gains some support from the empirical research.

\subsection{Variables and models}

We apply regression models. The dependent variables are defined as follows.

The ideal number of children is measured by the question: "How many children do you think is the ideal number of children for a family to have in this country?" The answers included undefined numbers such as ' 2 or 3', ' 3 or 4 '. The latter were rounded to the lower number, in these cases to 2 and 3 correspondingly. The results would not have changed substantially if the numbers had been rounded to the upper one, or if midpoints, for example 2.5, had been inserted. The variable used includes the five categories of $0,1,2,3,4$ or more children. Ordered logistic models were applied.

A second dependent variable used was the expected number of children for childless women. Respondents who answered positively to the question about their intentions to have children ("Do you want to have children of your own some time?") were asked about the number of children they would like to ever have. The results were estimated using linear regressions.

Intentions were measured with the question "Do you want to have another child sometime?" for women who have at least one child. Answer options were "yes", "no" and "don't know". The latter was included because of the sizeable number of uncertain respondents. In fact, on average 15.7\% (std.dev.: 8.4) of female respondents below age 40 were undecided whether to intend a second child, and $14.4 \%$ (std.dev.: 6.2 ) indicated that they did not know whether to want a third child. Related results for religious respondents were nearly identical. Morgan argued that the inclusion of uncertain fertility intentions should not be dispensed with and proposed that they take up a middle position between certain intentions to have or have not a child in the future (Morgan 1981: 267). We applied ordered logistic models to the variable thus constructed.

We do not analyse intentions to have a first child. Contemporary low fertility levels are mainly due to the low number of second and higher-order children, and the increase in childlessness only explains a small proportion of the overall recent fertility decline in Europe. Expectably, most respondents who have no children declare their willingness to have a child. Thus the variance of this variable is small and it is unsuitable for the application of statistical models in most of the countries included in this analysis. 
The influence of explanatory and control variables on the actual number of children was estimated by means of linear regressions.

All variables on religiosity were used as qualitative ones. The levels are defined as follows:

- Self-assessed religiosity: three categories of yes, somewhat, no;

- Religious affiliation: Catholics, Protestants, Orthodox and non-religious. Muslims are only included in Bulgaria. The actual categories depend on the availability of each denomination in the country under study. The category of freethinkers was excluded from the analysis together with all other religions;

- Church attendance: two levels, at least monthly and less than monthly, are considered;

- Importance of God: three categories of (1) very important and important, (2) neither important nor unimportant, (3) unimportant and very unimportant are defined.

For reason of comparability we employed the same reference category in one set of models for all countries. If, however, a given group was too minor to be suited for the statistical models we changed it in the country concerned.

In all models we apply one and the same basic set of independent variables to control for age, marital status, level of education and employment. We also experimented with the variable on the number of children of the respondent's mother. Since there were only minor changes in the results, however, we regard this variable as endogenous and did not introduce it in the final models.

The variables were defined as follows:

- Age: four age groups are used defined for the intervals $<25$ years, 25-29, 3034 and 35-39 completed years of age. Respondents aged 40 and above were skipped from the analyses;

- Marital status: the following four states of being single, living in a nonmarital cohabitation, being married and divorced or widowed respectively are considered;

- Level of education: three levels are considered as follows: (1) below secondary, (2) secondary completed and (3) higher than secondary;

- Employment: the two states of being employed or unemployed at the time of interview.

When studying intentions we include a different additional control variable. It describes the interval since the birth of the preceding child. With respect to intentions for a second child this is the period since the birth of the first child, and for intentions to have a third child it is the period since the birth of the second 
one. Birth order is defined according to the number of children being alive at the time of interview. The time since the last birth is measured in months.

The control variables are not analysed in this paper, nor are they shown in the model results discussed in the next chapter. The purpose of the model use is only to track the significance of religion on ideals, intentions and behaviour, and not to study the latter.

When studying intentions to have a child of a particular birth order we select the women exposed to the risk of birth of child of this order, out of all women. We experimented with Heckman selection models; the results did not support a significant effect of this selection and therefore we do not discuss them.

We applied the models for each country separately. Another way to proceed would be to pool the datasets and add a country dummy (Adsera 2006b). Since we are interested in the effect of religiosity within a given context we studied individual countries. Also, the size of the samples allows for such an approach.

\section{Descriptive analysis}

In the first piece of analysis we present some selected descriptive results. Table 3 shows our dependent variables by the different levels of self-assessed religiosity. In all cases, with the exception of Bulgaria and Latvia, the mean ideal number of religious people exceeds that of the non-religious, on average by 0.17 children.

Considering the expected number of children for childless women reveals that for the religious group the mean number lies above the replacement level of 2.05 whereas non-religious childless women expect 1.85 children on average.

The proportion of religious one-child mothers who want a second child lies on average about $8 \%$ higher than the proportion of non-religious women. Religiosity appears to be more relevant for the intention to have a second than to have a third child. The differences between religious and non-religious women are markedly more pronounced in the former than in the latter case. Bulgaria and the Czech Republic are exceptions to this rule.

The difference in the actual number of children between religious and nonreligious women amounts to 0.22 children on average and is largest in Greece, Spain, Austria and Slovenia. 
Table 3:

Ideal number of children, intentions to have a second and third child respectively and expected number of children by self-assessed religiosity, women below age 40 (weighted)

\begin{tabular}{|c|c|c|c|c|c|c|}
\hline & $\begin{array}{c}\text { Self- } \\
\text { assessed } \\
\text { religiosity }\end{array}$ & $\begin{array}{c}\text { Mean ideal } \\
\text { number of } \\
\text { children }\end{array}$ & $\begin{array}{c}\text { Mean expected } \\
\text { number of } \\
\text { children; } \\
\text { childless women } \\
\text { aged 18-35 } \\
\end{array}$ & $\begin{array}{l}\text { Intention } \\
\text { to have a } \\
\text { second } \\
\text { child (in } \\
\text { per cent) }\end{array}$ & $\begin{array}{c}\text { Intention } \\
\text { to have a } \\
\text { third child } \\
\text { (in per } \\
\text { cent) } \\
\end{array}$ & $\begin{array}{c}\text { Mean } \\
\text { actual } \\
\text { number of } \\
\text { children }\end{array}$ \\
\hline \multirow{2}{*}{ Austria } & No & 2.20 & 1.77 & 50.1 & 16.3 & 1.01 \\
\hline & Yes & 2.33 & 2.01 & 59.4 & 16.8 & 1.39 \\
\hline \multirow[t]{3}{*}{ Bulgaria } & No & 2.35 & 1.88 & 38.9 & 8.5 & 1.19 \\
\hline & Somewhat & 2.33 & 1.86 & 31.4 & 7.4 & 1.20 \\
\hline & Yes & 2.34 & 1.83 & 39.3 & 13.6 & 1.18 \\
\hline \multirow[t]{3}{*}{ Czech Rep. } & No & 2.06 & 1.95 & 56.2 & 6.6 & 1.23 \\
\hline & Somewhat & 2.17 & 2.01 & 57.4 & 8.2 & 1.30 \\
\hline & Yes & 2.35 & 2.33 & 63.9 & 30.7 & 1.42 \\
\hline \multirow[t]{3}{*}{ Estonia } & No & 2.80 & 1.93 & 72.6 & 31.5 & 1.48 \\
\hline & Somewhat & 2.84 & 1.84 & 64.5 & 29.4 & 1.71 \\
\hline & Yes & 2.81 & s.n. & 63.6 & s.n. & 1.43 \\
\hline \multirow[t]{3}{*}{ Finland } & No & 2.63 & 1.86 & 68.8 & 35.8 & 1.09 \\
\hline & Somewhat & 2.77 & 2.15 & 61.9 & 36.1 & 1.33 \\
\hline & Yes & 2.92 & 2.22 & s.n. & 45.3 & 1.42 \\
\hline \multirow{3}{*}{$\begin{array}{l}\text { Germany, } \\
\text { East }\end{array}$} & No & 1.82 & 1.46 & 22.9 & 3.4 & 1.44 \\
\hline & Somewhat & 1.97 & 1.62 & 26.2 & 4.9 & 1.52 \\
\hline & Yes & 2.19 & s.n. & s.n. & 18.0 & 1.55 \\
\hline \multirow{3}{*}{$\begin{array}{l}\text { Germany, } \\
\text { West }\end{array}$} & No & 2.05 & 1.58 & 30.0 & 9.3 & 0.94 \\
\hline & Somewhat & 2.21 & 1.76 & 25.8 & 8.8 & 1.14 \\
\hline & Yes & 2.23 & 1.96 & 50.4 & 7.7 & 1.22 \\
\hline \multirow[t]{3}{*}{ Greece } & No & 2.52 & 2.21 & s.n. & s.n. & 0.66 \\
\hline & Somewhat & 2.61 & 2.28 & 74.4 & 20.4 & 0.75 \\
\hline & Yes & 2.73 & 2.29 & 77.1 & 27.5 & 1.11 \\
\hline \multirow[t]{3}{*}{ Hungary } & No & 2.28 & 2.03 & 43.5 & 7.7 & 1.38 \\
\hline & Somewhat & 2.32 & 2.01 & 53.5 & 6.4 & 1.42 \\
\hline & Yes & 2.34 & 2.23 & 49.8 & 8.7 & 1.48 \\
\hline \multirow[t]{3}{*}{ Italy } & No & 2.13 & 1.80 & 42.1 & 9.5 & 0.58 \\
\hline & Somewhat & 2.22 & 2.08 & 36.0 & s.n. & 0.70 \\
\hline & Yes & 2.38 & 2.12 & 60.6 & 14.5 & 0.90 \\
\hline \multirow[t]{3}{*}{ Latvia } & No & 2.44 & 2.10 & 44.3 & 13.5 & 1.36 \\
\hline & Somewhat & 2.38 & 2.01 & 48.4 & 12.6 & 1.32 \\
\hline & Yes & 2.44 & 2.21 & 51.3 & 12.2 & 1.32 \\
\hline \multirow[t]{3}{*}{ Lithuania } & No & 2.28 & 1.54 & 53.5 & 18.4 & 1.05 \\
\hline & Somewhat & 2.30 & 1.95 & 57.4 & 11.4 & 1.18 \\
\hline & Yes & 2.40 & 1.92 & 57.6 & 19.2 & 1.17 \\
\hline \multirow[t]{3}{*}{ Poland } & No & s.n. & s.n. & s.n. & s.n. & s.n. \\
\hline & Somewhat & 2.15 & s.n. & s.n. & s.n. & 0.95 \\
\hline & Yes & 2.36 & 1.37 & 51.5 & 11.8 & 1.45 \\
\hline
\end{tabular}

(continued on the next page) 


\begin{tabular}{|c|c|c|c|c|c|c|}
\hline & $\begin{array}{c}\text { Self- } \\
\text { assessed } \\
\text { religiosity }\end{array}$ & $\begin{array}{c}\text { Mean ideal } \\
\text { number of } \\
\text { children }\end{array}$ & $\begin{array}{c}\text { Mean expected } \\
\text { number of } \\
\text { children; } \\
\text { childless women } \\
\text { aged 18-35 } \\
\end{array}$ & $\begin{array}{l}\text { Intention } \\
\text { to have a } \\
\text { second } \\
\text { child (in } \\
\text { per cent) } \\
\end{array}$ & $\begin{array}{l}\text { Intention } \\
\text { to have a } \\
\text { third child } \\
\text { (in per } \\
\text { cent) } \\
\end{array}$ & $\begin{array}{c}\text { Mean } \\
\text { actual } \\
\text { number of } \\
\text { children }\end{array}$ \\
\hline \multirow[t]{3}{*}{ Slovenia } & No & 2.10 & 2.07 & 62.3 & 20.4 & 0.90 \\
\hline & Somewhat & 2.19 & 2.11 & 63.5 & 15.8 & 1.16 \\
\hline & Yes & 2.40 & 2.37 & 71.2 & 25.6 & 1.29 \\
\hline \multirow[t]{3}{*}{ Spain } & No & 2.18 & 1.94 & 57.7 & 21.2 & 0.67 \\
\hline & Somewhat & 2.26 & 2.11 & 74.5 & 21.2 & 0.88 \\
\hline & Yes & 2.42 & 2.31 & 72.6 & 23.9 & 1.05 \\
\hline \multirow[t]{2}{*}{ Switzerland } & No & 2.31 & 1.64 & s.n. & 16.1 & 0.74 \\
\hline & Yes & 2.45 & 2.25 & 63.8 & 16.4 & 1.05 \\
\hline
\end{tabular}

Note: s.n. indicates that $\mathrm{n}<30$ cases

\section{Results and interpretations}

The estimates about the association between religious affiliation and the five response variables (Table 4) disclose an explicit relation between them.

The ideal number of children is significantly higher for members of a certain Christian church than for the non-affiliated. This inference holds throughout the countries with the exception of Bulgaria and Poland (the number of non-religious persons in this country is very small), and of Latvia where there is no difference between Catholics and the non-affiliated but the Protestants show a higher ideal number of children.

The effect of denomination is traceable as well: in the Baltic countries, the Orthodox have a significantly lower ideal number of children than the reference group. In general, there is no statistically significant difference between Catholics and Protestants with the exceptions of Latvia and Switzerland.

Concerning the expected number of children for childless women, in 9 out of the 14 countries under study non-religious women differ from the religious base category. Protestants and Catholics differ in Latvia, but not in western Germany, Switzerland and Hungary. 
Table 4:

Association between religious affiliation and ideal number of children, childbearing intentions and expected number of children: ordered logistic regression results for women below age 40

\begin{tabular}{|c|c|c|c|c|c|c|}
\hline & & $\begin{array}{c}\text { Ideal } \\
\text { number of } \\
\text { children }\end{array}$ & $\begin{array}{c}\text { Expected } \\
\text { number of } \\
\text { children }^{\mathrm{a}}\end{array}$ & $\begin{array}{c}\text { Intention to } \\
\text { have a } \\
\text { second child }\end{array}$ & $\begin{array}{c}\text { Intention } \\
\text { to have a } \\
\text { third child }\end{array}$ & $\begin{array}{c}\text { Actual } \\
\text { number of } \\
\text { children }\end{array}$ \\
\hline \multirow[t]{3}{*}{ Austria } & Cath. (base) & 0 & 0 & 0 & 0 & 0 \\
\hline & Protestant & 0.04 & s.n. & s.n. & 0.57 & -0.03 \\
\hline & Non-relig. & $-0.48 * * *$ & $-0.31 * * *$ & $-0.67 * * *$ & -0.03 & $-0.07 * *$ \\
\hline \multirow{2}{*}{$\begin{array}{l}\text { Belgium } \\
\text { (Flanders) }\end{array}$} & Cath. (base) & 0 & 0 & 0 & 0 & 0 \\
\hline & Non-relig. & $-0.48 * * *$ & $-0.37 * * *$ & $-0.81 * *$ & -0.09 & -0.06 \\
\hline \multirow[t]{3}{*}{ Bulgaria } & Orth. (base) & 0 & 0 & 0 & 0 & 0 \\
\hline & Muslim & 0.16 & s.n. & s.n. & 0.26 & $0.28 * * *$ \\
\hline & Non-relig. & 0.12 & 0.00 & 0.06 & -0.25 & $0.11^{* * *}$ \\
\hline \multirow[t]{3}{*}{ Estonia } & Prot. (base) & 0 & 0 & 0 & 0 & 0 \\
\hline & Orthodox & $-1.38 * * *$ & s.n. & $-1.21 * *$ & -0.69 & -0.09 \\
\hline & Non-relig. & $-0.26^{* *}$ & -0.11 & -0.24 & -0.06 & $-0.13 * *$ \\
\hline \multirow{3}{*}{$\begin{array}{l}\text { Germany, } \\
\text { East }\end{array}$} & Catholic & 0.36 & s.n. & s.n. & 0.29 & 0.02 \\
\hline & Prot. (base) & 0 & 0 & 0 & 0 & 0 \\
\hline & Non-relig. & $-0.56^{* * *}$ & -0.20 & -0.12 & -0.35 & -0.05 \\
\hline \multirow{3}{*}{$\begin{array}{l}\text { Germany, } \\
\text { West }\end{array}$} & Cath. (base) & 0 & 0 & 0 & 0 & 0 \\
\hline & Protestant & -0.05 & -0.09 & $-0.44 *$ & -0.37 & $0.07 * *$ \\
\hline & Non-relig. & $-0.50 * * *$ & $-0.26^{* * *}$ & $-0.45 * *$ & $-0.53 * *$ & -0.04 \\
\hline \multirow[t]{2}{*}{ Greece } & Orth. (base) & 0 & 0 & s.n. & 0 & 0 \\
\hline & Non-relig. & $-0.35^{*}$ & -0.09 & s.n. & -0.19 & -0.10 \\
\hline \multirow[t]{3}{*}{ Hungary } & Cath. (base) & 0 & 0 & 0 & 0 & 0 \\
\hline & Protestant & 0.07 & 0.09 & -0.29 & 0.19 & 0.00 \\
\hline & Non-relig. & $-0.15^{*}$ & -0.07 & $-0.34 *$ & -0.13 & 0.02 \\
\hline \multirow[t]{2}{*}{ Italy } & Cath. (base) & 0 & 0 & 0 & 0 & 0 \\
\hline & Non-relig. & $-0.77 * * *$ & $-0.32 * * *$ & -0.19 & 0.01 & $-0.12 * * *$ \\
\hline \multirow[t]{4}{*}{ Latvia } & Cath. (base) & 0 & 0 & 0 & 0 & 0 \\
\hline & Protestant & $0.80^{* * *}$ & $0.25 * *$ & $0.71 * *$ & 0.39 & $0.13 * *$ \\
\hline & Orthodox & $-0.84 * * *$ & -0.10 & -0.12 & -0.01 & $-0.24 * * *$ \\
\hline & Non-relig. & 0.05 & 0.08 & -0.19 & 0.12 & -0.04 \\
\hline \multirow[t]{3}{*}{ Lithuania } & Cath. (base) & 0 & 0 & 0 & 0 & 0 \\
\hline & Orthodox & $-0.77 * * *$ & s.n. & -0.24 & -0.13 & -0.02 \\
\hline & Non-relig. & $-0.36 * *$ & $-0.37 * *$ & -0.20 & -0.04 & $-0.14 * * *$ \\
\hline \multirow[t]{2}{*}{ Poland } & Cath. (base) & 0 & s.n. & s.n. & 0 & 0 \\
\hline & Non-relig. & -0.27 & s.n. & s.n. & -1.7 & -0.18 \\
\hline \multirow[t]{2}{*}{ Slovenia } & Cath. (base) & 0 & 0 & 0 & 0 & 0 \\
\hline & Non-relig. & $-0.54 * * *$ & $-0.19 * *$ & $-0.46^{*}$ & -0.26 & $-0.17 * * *$ \\
\hline \multirow[t]{2}{*}{ Spain } & Cath. (base) & 0 & 0 & 0 & 0 & 0 \\
\hline & Non-relig. & $-0.55 * * *$ & $-0.31 * * *$ & $-0.63 * * *$ & -0.17 & $-0.12 * * *$ \\
\hline \multirow[t]{3}{*}{ Switzerland } & Cath. (base) & 0 & 0 & 0 & 0 & 0 \\
\hline & Protestant & $-0.29 * * *$ & -0.02 & -0.28 & $-0.42 * *$ & 0.05 \\
\hline & Non-relig. & $-0.36^{* *}$ & $-0.42 * *$ & $-0.89^{* *}$ & -0.47 & $-0.14^{* *}$ \\
\hline
\end{tabular}

Notes: ${ }^{a}$ childless women (aged 18-35); ${ }^{* * *}$ denotes $\mathrm{p}>0.01 ;{ }^{* *} \mathrm{p}>0.05 ;{ }^{*} \mathrm{p}>0.10$; s.n. indicates that $\mathrm{n}<30$ cases. 
The association between religiosity and intentions to have a second or third child is also positive, although in fewer countries a statistically significant difference between religious and non-religious women can be observed as compared to ideals. However, the signs of the coefficients support the hypothesis that affiliated people have higher odds of intending another child. For the intentions to have a second child, the differences by denomination resemble those observed for the ideals: in the Baltic countries Orthodox adherents have lower odds than Catholics or Protestants, and in some countries, namely West Germany, Hungary and Switzerland, the coefficients indicate higher intentions for Catholics as compared to Protestants.

With regard to the intentions to have a third child it is only in western Germany and Switzerland that statistically significant differences can be observed between non-religious people and Catholics and Catholics and Protestants, respectively.

The actual number of children differs in two thirds of the countries significantly between the affiliated and their non-religious counterparts. In Bulgaria, western Germany and Latvia we can observe differences between denominations as well. Judging from the p-values, affiliation plays a more important role for the actual number of children than for fertility intentions. Nevertheless, the fact that we observe high significance levels of religious measures for many countries provides only a limited indication and not conclusive evidence of the higher importance of religious measures for some dependent variables than for others.

Relating our empirical results back to the hypotheses, we can confirm our first one which stated that ideals, expected number of children, intentions and actual number of children are higher for the affiliated than for the non-affiliated. Since the dataset regrettably does not contain the distinction between mainline and conservative Protestants, we can neither draw conclusions for the different groups of Protestants, nor fully explore the differences between Protestants and Catholics in particular.

We have further attained first insights into addressing the fifth hypothesis which assumed that religious measures are more strongly linked with ideals than with intentions. The data so far are in line with this expectation. We also hypothesised that religious measures should matter more for intentions than for actual behaviour. The results as yet do not support this expectation, but we will resume the question after further estimations.

As to church attendance (Table 5) there are statistically significant differences between those who attend church less and those who attend more than monthly at the low $p$-value of $p>0.01$, Latvia constituting the only exception. Apart from Bulgaria where the frequency of church attendance is negatively associated with the ideal number of children, there are positive relations in all other countries. 
Table 5:

Association between attendance of religious services and ideal number of children, childbearing intentions and expected number of children: ordered logistic regression results for women below age 40 (\#)

\begin{tabular}{|c|c|c|c|c|c|c|}
\hline & & $\begin{array}{c}\text { Ideal } \\
\text { number of } \\
\text { children }\end{array}$ & $\begin{array}{c}\text { Expected } \\
\text { number of } \\
\text { children }^{a}\end{array}$ & $\begin{array}{c}\text { Intention to } \\
\text { have a second } \\
\text { child }\end{array}$ & $\begin{array}{c}\text { Intention to } \\
\text { have a } \\
\text { third child }\end{array}$ & $\begin{array}{c}\text { Actual } \\
\text { number of } \\
\text { children }\end{array}$ \\
\hline \multirow[t]{2}{*}{ Bulgaria } & $\begin{array}{c}\text { Less than } \\
\text { monthly }\end{array}$ & 0 & 0 & 0 & 0 & 0 \\
\hline & $\begin{array}{l}\text { At least } \\
\text { monthly }\end{array}$ & $-0.50 * * *$ & -0.06 & $-0.71 * * *$ & 0.21 & $-0.19 * * *$ \\
\hline \multirow{2}{*}{$\begin{array}{l}\text { Czech } \\
\text { Republic }\end{array}$} & Less t. m. & 0 & 0 & s.n. & 0 & 0 \\
\hline & At least $\mathrm{m}$. & $0.70 * * *$ & $0.37 * * *$ & s.n. & $1.61 * * *$ & $0.17 * * *$ \\
\hline \multirow[t]{2}{*}{ Finland } & Less t. m. & 0 & 0 & s.n. & 0 & 0 \\
\hline & At least $\mathrm{m}$. & $0.79 * * *$ & $0.58 * * *$ & s.n. & 0.44 & $0.26 * * *$ \\
\hline \multirow{2}{*}{$\begin{array}{l}\text { Germany, } \\
\text { East }\end{array}$} & Less t. m. & 0 & 0 & 0 & 0 & 0 \\
\hline & At least $\mathrm{m}$. & $0.56^{* * *}$ & 0.18 & 0.27 & 0.41 & 0.04 \\
\hline \multirow{2}{*}{$\begin{array}{l}\text { Germany, } \\
\text { West }\end{array}$} & Less t. m. & 0 & 0 & 0 & 0 & 0 \\
\hline & At least $\mathrm{m}$. & $0.50 * * *$ & $0.25 * * *$ & $0.74 * * *$ & 0.33 & $0.14 * * *$ \\
\hline \multirow[t]{2}{*}{ Greece } & Less t. m. & 0 & 0 & 0 & 0 & 0 \\
\hline & At least $\mathrm{m}$. & $0.51 * * *$ & $0.16^{* * *}$ & $0.50^{*}$ & $0.63^{* * *}$ & $0.05^{*}$ \\
\hline \multirow[t]{2}{*}{ Hungary } & Less t. m. & 0 & 0 & 0 & 0 & 0 \\
\hline & At least $\mathrm{m}$. & $0.38 * * *$ & $0.16^{* *}$ & 0.44 & 0.29 & 0.01 \\
\hline \multirow[t]{2}{*}{ Italy } & Less t. m. & 0 & 0 & 0 & 0 & 0 \\
\hline & At least $\mathrm{m}$. & $0.28 * * *$ & $0.16^{* * *}$ & $0.53^{* * *}$ & $0.40 * *$ & $0.07 * * *$ \\
\hline \multirow[t]{2}{*}{ Latvia } & Less t. m. & 0 & 0 & 0 & 0 & 0 \\
\hline & At least $\mathrm{m}$. & -0.05 & $0.23 * * *$ & $0.49 *$ & 0.10 & -0.08 \\
\hline \multirow[t]{2}{*}{ Norway } & Less t. m. & 0 & 0 & s.n. & 0 & 0 \\
\hline & At least $\mathrm{m}$. & $1.19 * * *$ & $0.27 * * *$ & s.n. & $0.53^{*}$ & $0.11^{* * *}$ \\
\hline \multirow[t]{2}{*}{ Poland } & Less t. m. & 0 & 0 & 0 & 0 & 0 \\
\hline & At least $\mathrm{m}$. & $0.54 * * *$ & $0.14 * *$ & $0.97 * * *$ & $1.20 * * *$ & $0.12 * *$ \\
\hline \multirow[t]{2}{*}{ Slovenia } & Less t. m. & 0 & 0 & 0 & 0 & 0 \\
\hline & At least $\mathrm{m}$. & $0.73 * * *$ & $0.25 * *$ & 0.35 & $0.39 * *$ & 0.19 *** \\
\hline \multirow[t]{2}{*}{ Spain } & Less t. m. & 0 & 0 & 0 & 0 & 0 \\
\hline & At least $\mathrm{m}$. & $0.52 * * *$ & $0.29 * * *$ & 0.09 & -0.11 & $0.05 *$ \\
\hline \multirow[t]{2}{*}{ Sweden } & Less t. m. & 0 & 0 & 0 & 0 & 0 \\
\hline & At least $\mathrm{m}$. & $0.56^{* * *}$ & $0.47 * * *$ & -0.52 & 0.43 & 0.01 \\
\hline \multirow{2}{*}{$\begin{array}{l}\text { Switzer- } \\
\text { land }\end{array}$} & Less t. m. & 0 & 0 & 0 & 0 & 0 \\
\hline & At least $\mathrm{m}$. & $0.72 * * *$ & $0.34 * * *$ & $1.06^{* *}$ & $0.64 * * *$ & $0.28 * * *$ \\
\hline
\end{tabular}

Notes: (\#) The base category is "Less than monthly";

${ }^{a}$ childless women (aged 18-35);

$* * *$ denotes $\mathrm{p}>0.01 ; * * \mathrm{p}>0.05 ; * \mathrm{p}>0.10$;

s.n. indicates that $\mathrm{n}<30$ cases. 
With regard to the expected number of children the differences between frequent and infrequent churchgoers become insignificant in Bulgaria and eastern Germany.

As observed in the previous models, less countries than in the case of ideals, namely 7 out of 12 , differ significantly with respect to the intentions to have a second child and 7 out of 15 differ when looking at the intentions to have a third child. In all countries but one or two, respectively, the coefficients go in the expected direction, however.

The religious variable again shows increased importance for actual behaviour as compared to fertility intentions. In four countries, eastern Germany, Hungary, Latvia and Sweden there is no statistical significant difference between the two categories.

To summarise, we can confirm our second hypothesis of the positive association between church attendance and fertility ideals, intentions and behaviour. In line with our third hypothesis we have found that church attendance is a stronger predictor of fertility than affiliation alone. Again there is evidence that religion is more important for ideals than for intentions and for the actual number of children than for intentions.

Next, we investigate the two measures of subjective religiosity, i.e., not necessarily bound to an organisation, namely self-assessed religiosity (Table 6) and importance of God (Table 7).

The estimates about the association of self-assessed religiosity with the dependent variables reveal an explicit relation, though to a varying degree, between them. The higher the religiosity, the higher the ideal number of children, and the statistical significance of the association is valid at a low $p$-value, $p>0.01$, in most countries. This inference holds throughout all cases, with the exception of those countries where fertility ideals do not differ by religiosity: Bulgaria, Estonia and Switzerland. The results indicate the significance of the category 'somewhat' in the case of self-assessed religiosity: out of 16 countries where it was applied, in 6 countries it was found to be statistically different from the category identified with the answer 'no'. In general, in some countries where the measure of church attendance shows significant results, self-assessed religiosity does not. One explanation could be that churchgoers constitute a subgroup of those who indicate to be religious which then entails that the former are more homogeneous and show a more pronounced behaviour. The idea that the care for children prevents mothers from going to church does not seem to be significant.

As compared to the influence of self-assessed religiosity on ideals, the religious variable is relevant for the expected number of children in fewer countries. 
Table 6:

Association between self-assessed religiosity and ideal number of children, childbearing intentions and expected number of children: ordered logistic regression results for women below age 40 (\#)

\begin{tabular}{|c|c|c|c|c|c|c|}
\hline & & $\begin{array}{c}\text { Ideal } \\
\text { number of } \\
\text { children }\end{array}$ & $\begin{array}{c}\text { Expected } \\
\text { number of } \\
\text { children }^{\mathrm{a}} \\
\end{array}$ & $\begin{array}{l}\text { Intention to } \\
\text { have a } \\
\text { second child }\end{array}$ & $\begin{array}{c}\text { Intention to } \\
\text { have a third } \\
\text { child }\end{array}$ & $\begin{array}{c}\text { Actual } \\
\text { number of } \\
\text { children }\end{array}$ \\
\hline \multirow[t]{2}{*}{ Austria } & No & 0 & 0 & 0 & 0 & 0 \\
\hline & Yes & $0.47 * * *$ & $0.31 * * *$ & $0.68 * * *$ & 0.06 & $0.05^{*}$ \\
\hline \multirow[t]{3}{*}{ Bulgaria } & No & 0 & 0 & 0 & 0 & 0 \\
\hline & Somewhat & -0.10 & 0.01 & -0.05 & 0.10 & $-0.07 * *$ \\
\hline & Yes & -0.12 & 0.03 & -0.01 & $0.75 * * *$ & $-0.10 * *$ \\
\hline Czech & No & 0 & 0 & 0 & 0 & 0 \\
\hline \multirow[t]{2}{*}{ Republic } & Somewhat & $0.30^{*}$ & 0.09 & 0.20 & $0.82 * * *$ & 0.04 \\
\hline & Yes & $0.78 * * *$ & $0.38 * * *$ & 0.41 & $1.60 * * *$ & $0.12 * *$ \\
\hline \multirow[t]{3}{*}{ Estonia } & No & 0 & 0 & 0 & 0 & 0 \\
\hline & Somewhat & 0.11 & -0.07 & -0.09 & -0.05 & $0.12 * *$ \\
\hline & Yes & 0.05 & s.n. & -0.55 & 0.40 & 0.05 \\
\hline \multirow[t]{3}{*}{ Finland } & No & 0 & 0 & 0 & 0 & 0 \\
\hline & Somewhat & $0.34 * * *$ & $0.27 * * *$ & -0.22 & 0.08 & 0.04 \\
\hline & Yes & $0.73 * * *$ & $0.38 * *$ & s.n. & 0.26 & $0.16^{* *}$ \\
\hline \multirow{3}{*}{$\begin{array}{l}\text { Germany, } \\
\text { East }\end{array}$} & No & 0 & 0 & 0 & 0 & 0 \\
\hline & Somewhat & $0.48 * * *$ & 0.10 & 0.20 & $0.48^{*}$ & 0.05 \\
\hline & Yes & $1.17 * * *$ & s.n. & s.n. & $1.09 * *$ & 0.10 \\
\hline \multirow{3}{*}{$\begin{array}{l}\text { Germany, } \\
\text { West }\end{array}$} & No & 0 & 0 & 0 & 0 & 0 \\
\hline & Somewhat & $0.47 * * *$ & $0.21 * * *$ & 0.12 & $0.42 *$ & $0.06^{*}$ \\
\hline & Yes & $0.54 * * *$ & $0.37 * * *$ & $0.97 * * *$ & -0.02 & $0.10 * *$ \\
\hline \multirow[t]{3}{*}{ Greece } & No & $-0.43^{* *}$ & -0.13 & s.n. & -0.83 & -0.11 \\
\hline & Somewhat & -0.17 & -0.04 & 0.35 & -0.55 & -0.05 \\
\hline & Yes & 0 & 0 & 0 & 0 & 0 \\
\hline \multirow[t]{3}{*}{ Hungary } & No & 0 & 0 & 0 & 0 & 0 \\
\hline & Somewhat & 0.12 & -0.01 & 0.26 & 0.16 & -0.03 \\
\hline & Yes & $0.19 * *$ & $0.18 * *$ & 0.30 & 0.26 & -0.01 \\
\hline \multirow[t]{3}{*}{ Italy } & No & 0 & 0 & 0 & 0 & 0 \\
\hline & Somewhat & 0.31 & $0.27 * *$ & -0.30 & s.n. & -0.02 \\
\hline & Yes & $0.80 * * *$ & $0.32 * * *$ & 0.22 & -0.01 & $0.12 * * *$ \\
\hline \multirow[t]{3}{*}{ Latvia } & No & 0 & 0 & 0 & 0 & 0 \\
\hline & Somewhat & $-0.19^{*}$ & -0.10 & 0.30 & -0.02 & -0.04 \\
\hline & Yes & -0.01 & 0.10 & 0.27 & -0.06 & 0.04 \\
\hline \multirow[t]{3}{*}{ Lithuania } & No & 0 & 0 & 0 & 0 & 0 \\
\hline & Somewhat & 0.13 & $0.45 * *$ & 0.17 & -0.40 & $0.15^{* * *}$ \\
\hline & Yes & $0.43 * * *$ & $0.41 * *$ & 0.23 & 0.25 & $0.12 * *$ \\
\hline \multirow[t]{3}{*}{ Poland } & No & $-0.44 *$ & s.n. & s.n. & $(+)$ & -0.16 \\
\hline & Somewhat & -0.14 & s.n. & s.n. & & -0.19 \\
\hline & Yes & 0 & s.n. & s.n. & & 0 \\
\hline
\end{tabular}

(continued on the next page) 
Table 6 (continued)

\begin{tabular}{ll|ccccc}
\hline & \multicolumn{1}{|c}{$\begin{array}{c}\text { Ideal } \\
\text { number of } \\
\text { children }\end{array}$} & $\begin{array}{c}\text { Expected } \\
\text { number of } \\
\text { children }\end{array}$ & $\begin{array}{c}\text { Intention to } \\
\text { have a } \\
\text { second child }\end{array}$ & $\begin{array}{c}\text { Intention to } \\
\text { have a third } \\
\text { child }\end{array}$ & $\begin{array}{c}\text { Actual } \\
\text { number of } \\
\text { children }\end{array}$ \\
\hline Slovenia & No & 0 & 0 & 0 & 0 & 0 \\
& Somewhat & 0.14 & 0.00 & 0.33 & 0.00 & 0.06 \\
& Yes & $0.76^{* * *}$ & $0.26^{* * *}$ & $0.52^{*}$ & $0.43^{*}$ & $0.21 * * *$ \\
\hline Spain & No & 0 & 0 & 0 & 0 & 0 \\
& Somewhat & $0.21^{*}$ & $0.19 * *$ & $0.69 * *$ & 0.14 & $0.11^{* * *}$ \\
& Yes & $0.64 * * *$ & $0.37 * * *$ & $0.59 * *$ & 0.22 & $0.13 * * *$ \\
\hline Switzer- & No & 0 & 0 & 0 & 0 & 0 \\
land & Yes & 0.23 & $0.40 * *$ & $0.78 *$ & 0.25 & $0.17 * * *$ \\
\hline
\end{tabular}

Notes: (\#) The base category is "No", except for Greece and Poland where it is "Yes";

a childless women (aged 18-35);

*** denotes $\mathrm{p}>0.01 ; * * \mathrm{p}>0.05$ and $* \mathrm{p}>0.10$;

s.n. indicates that $\mathrm{n}<30$ cases;

$(+)$ The model did not converge.

Intentions to have a second child are, in accordance with the findings so far, again less influenced by religiosity than the ideal number of children. In the case of self-assessed religiosity we find that it is statistically significant with higher odds to intend having a child in one third of the countries where the question was asked. However, in most countries, the signs of the coefficients support the hypothesis that more religious persons will have higher odds of intending to have a second child. For the intentions to have a third child it can be noted that while the variable loses significance in some countries, in others it gains in significance for the third child only. Examples for the first instance are Austria, Spain and Switzerland. In other countries, like Bulgaria or the Czech Republic, self-assessed religiosity gets important only when looking at the intentions to have a third child. This observation was less relevant for church attendance. In line with the pattern observed so far, the association with religiosity is again stronger for the actual number of children, only in eastern Germany, Greece, Hungary, Latvia and Poland do non-religious and religious women not differ significantly from each other. The importance of God (Table 7) turns out to be a relevant predictor as well, it is even significant for the ideal number of children in Latvia and Switzerland where religious and non-religious women did not differ with respect to the previous variables. Interestingly, unlike the other measures this one seems to be more relevant for the intentions to have a third than a second child. ${ }^{2}$

${ }^{2}$ We note that the assumption of a selection process in the transition to higher parities is plausible, even though our experiments with the Heckman selection models did not explicitly reveal such selectivity. The level of selection is likely to vary by country since the country-specific institutional and ideational setting facilitates or impedes transition to higher-order births. Those having two or more children are less selected in contexts in which progression to higher parities is comparatively easy. Our results are not straightforwardly interpretable in the light of this general deliberation since facility of childbearing has changed substantially over time. (We would like to thank Alicia Adsera for suggesting this idea.) 
Table 7:

Association between importance of God and ideal number of children, childbearing intentions and expected number of children: ordered logistic regression results for women below age 40 (\#)

\begin{tabular}{|c|c|c|c|c|c|c|}
\hline & & $\begin{array}{c}\text { Ideal } \\
\text { number of } \\
\text { children }\end{array}$ & $\begin{array}{c}\text { Expected } \\
\text { number of } \\
\text { children }^{\mathrm{a}}\end{array}$ & $\begin{array}{c}\text { Intention to } \\
\text { have a } \\
\text { second child }\end{array}$ & $\begin{array}{l}\text { Intention } \\
\text { to have a } \\
\text { third child }\end{array}$ & $\begin{array}{c}\text { Actual } \\
\text { number of } \\
\text { children } \\
\end{array}$ \\
\hline \multirow{3}{*}{$\begin{array}{l}\text { Belgium } \\
\text { (Flanders) }\end{array}$} & Unimportant & 0 & 0 & 0 & 0 & 0 \\
\hline & Neither-nor & 0.16 & 0.14 & 0.40 & -0.34 & 0.04 \\
\hline & Important & $0.48 * * *$ & $0.48 * * *$ & 0.32 & 0.05 & $0.09 * *$ \\
\hline Czech & Unimportant & 0 & 0 & 0 & 0 & 0 \\
\hline \multirow[t]{2}{*}{ Republic } & Neither - nor & 0.13 & 0.05 & $0.95 * * *$ & 0.27 & -0.01 \\
\hline & Important & $0.66^{* * *}$ & $0.27 * *$ & 0.66 & $1.38 * * *$ & $0.11 * *$ \\
\hline \multirow{3}{*}{$\begin{array}{l}\text { Germany, } \\
\text { East }\end{array}$} & Unimportant & 0 & 0 & 0 & 0 & 0 \\
\hline & Neither - nor & $0.41 * * *$ & 0.08 & 0.29 & $0.43 *$ & -0.01 \\
\hline & Important & $0.75^{* * *}$ & 0.17 & 0.10 & $0.68 * *$ & $0.09 * *$ \\
\hline \multirow{3}{*}{$\begin{array}{l}\text { Germany, } \\
\text { West }\end{array}$} & Unimportant & 0 & 0 & 0 & 0 & 0 \\
\hline & Neither - nor & $0.22 * *$ & $0.32 * * *$ & 0.30 & 0.36 & $0.06^{*}$ \\
\hline & Important & $0.56^{* * *}$ & $0.44 * * *$ & $0.47 * *$ & $0.78 * * *$ & $0.10 * * *$ \\
\hline \multirow[t]{3}{*}{ Greece } & Unimportant & $-0.89 * * *$ & $-0.28 * *$ & s.n. & s.n. & -0.02 \\
\hline & Neither - nor & $-0.63 * * *$ & -0.11 & s.n. & -0.76 & $-0.11^{*}$ \\
\hline & Important & 0 & 0 & s.n. & 0 & 0 \\
\hline \multirow[t]{3}{*}{ Hungary } & Unimportant & 0 & 0 & 0 & 0 & 0 \\
\hline & Neither - nor & 0.16 & 0.06 & 0.17 & $-0.37^{*}$ & 0.03 \\
\hline & Important & $0.27 * * *$ & $0.15 * *$ & $0.34^{*}$ & -0.03 & 0.01 \\
\hline \multirow[t]{3}{*}{ Latvia } & Unimportant & 0 & 0 & 0 & 0 & 0 \\
\hline & Neither - nor & $0.45^{* * *}$ & 0.14 & 0.08 & $1.00 * * *$ & $0.16 * * *$ \\
\hline & Important & $0.44 * * *$ & $0.20 * *$ & 0.27 & $0.90 * * *$ & $0.11 * *$ \\
\hline \multirow[t]{3}{*}{ Slovenia } & Unimportant & 0 & 0 & 0 & 0 & 0 \\
\hline & Neither - nor & $0.36 * * *$ & 0.07 & 0.21 & $0.51 * *$ & $0.12 * * *$ \\
\hline & Important & $0.92 * * *$ & 0.16 & $0.80 * * *$ & $0.77 * * *$ & $0.24 * * *$ \\
\hline \multirow[t]{3}{*}{ Spain } & Unimportant & 0 & 0 & 0 & 0 & 0 \\
\hline & Neither - nor & $0.42 * * *$ & $0.20 * *$ & $0.94 * * *$ & $-0.72 *$ & 0.06 \\
\hline & Important & $0.82 * * *$ & $0.44 * * *$ & $1.22 * * *$ & $-0.65 *$ & $0.09 * *$ \\
\hline \multirow{3}{*}{$\begin{array}{l}\text { Switzer- } \\
\text { land }\end{array}$} & Unimportant & 0 & 0 & 0 & 0 & 0 \\
\hline & Neither - nor & $0.23 *$ & $0.23 * *$ & -0.05 & $0.61 *$ & 0.07 \\
\hline & Important & $0.56^{* * *}$ & $0.27 * *$ & 0.30 & $1.21 * * *$ & $0.20 * * *$ \\
\hline
\end{tabular}

Notes: (\#) The base category is "Unimportant" except for Greece where it is "Important";

a childless women (aged 18-35);

$* * *$ denotes $\mathrm{p}>0.01 ; * * \mathrm{p}>0.05$ and $* \mathrm{p}>0.10$;

s.n. indicates that $\mathrm{n}<30$ cases. 
Concerning the former, only in Greece and Belgium no difference from the baseline category can be noticed. The coefficients in Hungary and Spain point in an unexpected direction. Again, importance of God is more relevant for the actual number of children than for intentions but the difference is modest.

Hence our forth hypothesis that predicted a positive association between subjective religiosity and ideals, intentions and behaviour is supported. We can now conclude that religiosity plays a more important role for ideals, i.e., for a value, than for intentions. This is in line with the theory of planned behaviour according to which it can be deduced that the impact of religion is weaker for intentions because they stay closer to behaviour as compared with ideals. This would mean that the observed strong impact of religion on the ideals loosens during the process of construction of intentions along with their direct precedents such as personal attitudes, subjective norms related to the behaviour and personal control over the behaviour.

Is this observation expected? If we considered the impact of one or more components of another social system on fertility ideals, intentions and behaviour, such as those related to education or labour, the observation would hardly be classified as unexpected. Education, work, culture and other social systems have an impact on fertility that has been studied by using diverse variables in model frameworks that account for the significant interrelationship among these systems. Religion, however, occupies a specific place in a society's social structure. Traditionally it has been a system that spans the entire societal structure and so permeates all other social systems like the ones mentioned above.

The influence of secularisation has brought an end to this hierarchical position of religion though. In contemporary times it is a part of the overall societal structure, one of many social systems that may interact with others (Dobbelaere 1995). This is what we observe in fertility. While religion may have a strong impact on impersonal values related to fertility, such as the ideal number of children, the impact is lower for intentions and behaviour because it is intermediated by components of other social systems. Apparently this conclusion holds where personal autonomy prevails and the impact of religious institutions and the restrictive power of norms have little relevance to a person's decision to have a child or not.

Unexpectedly though, religious measures have a stronger impact on the actual number of children than on fertility intentions. We might speculate that religious people's intentions are more stable and also that they are more prone to realise them than are non-religious people. Also, the observed higher importance for actual behaviour could possibly be the result of reverse causality as the turn of people toward religiosity when having children raises the impact of this variable. Thirdly, we can conjecture that we are facing selectivity in the way that religion is important for the transition to each parity and that the effects are thus cumulative and seem stronger when the overall number of children is considered. Lastly, we need to consider that the assumption of religion being a stronger determinant for 
intentions than for actual behaviour simply does not hold. At this point we can only offer plausible interpretations without assessing their validity.

\section{Conclusion}

Religion occupies a modest place in the research on contemporary fertility in Europe. Its impact has been considered in detail mainly in a historical perspective, for example in studies of the first demographic transition. Probably it is believed that persistent secularisation on the continent has rendered it a topic of secondary importance. However, the debate about the rise in new forms of religion indicates that religion is far from being extinguished. Regardless of whether these new forms stand for a revival of religion, its persistent importance, or are merely a stage in secularisation, there is sufficient ground to expect its further impact on demographic behaviour and fertility in particular.

We first gave some thought to the channels by which religion and fertility are linked. Beyond the conventional approach to the influence of religion, the actual teaching, we considered the impact of social networks and social capital, as well as factors like subjective wellbeing and uncertainty. There is no claim that the three issues we have raised here do indeed exhaust the background of religion's impact on demographic behaviour. However, based on the discussion we constructed plausible hypotheses the validity of which was empirically tested. It is also conceivable that other factors influence both fertility and religiosity, so that they are the outcome of a third variable rather than being directly associated with each other.

We did not discuss expected differences between denominations in our framework. This important topic deserves a special attention that is outside the scope of the paper.

We found that in most of the countries affiliated people have higher fertility ideals, higher odds of intending to have another child and a higher number of expected children than non-affiliated persons. The differences between Catholics and Protestants are not clear-cut which we assume to be partly due to the missing differentiation between mainline and conservative Protestants. Actual Protestant fertility is higher than that of Catholics in Latvia and western Germany. The FFS data allowed a comparison of fertility preferences among Orthodox adherents relative to Catholics and Protestants, at least in the three Baltic countries. Orthodox adherents revealed lower figures all over for ideals, intentions to have another child and actual fertility. Several reasons, in particular ethnicity (Russians dominate among the Orthodox adherents in the Baltic countries) and/or socioeconomic differences, could contribute to this result. It is, however, beyond the scope of this paper to explore these factors in detail.

We found a strong impact of attendance of religious services and can confirm that this measure is a slightly more relevant predictor than affiliation alone. Only 
Bulgaria constitutes an exception in that the coefficients are reversed as compared to the other countries. A higher intensity of self-assessed religiosity is positively associated with the measures of fertility even if slightly less strongly than attendance of religious services.

The stronger impact of religion on ideals as compared to intentions and behaviour is interpreted with the significant interactions that exist between the religious social system on the one hand and other systems on the other. Thus religion does not take a hierarchical position among the social systems where fertility is considered. Unexpectedly, religion exerts a larger impact on the actual number of children than on fertility intentions. Our results support those of Adsera (2006b) who studied fertility ideals in greater detail, e.g., across cohorts and sex, and confirmed the importance of church attendance and affiliation for the ideal number of children. Our study contributes to an increased understanding of the influence of additional religious measures, not only on ideals but also on intentions to have another child, as well as on the expected and actual number of children.

This discussion of course begs the question that can well be expected: if religion induces higher ideals, intentions and number of children, then why do countries with highest levels of religiosity, such as Italy and Spain, experience some of the lowest fertility levels in Europe? In this respect, Adsera (2006a) has pointed out the possible interrelation between the dramatic decline in fertility rates and the impressive decline in church attendance in Spain. We do not dispose of panel data to compare these trends, however. Another plausible answer could be based on the inference that religion as a social system interrelates with other social systems and this interaction may reduce its effect on fertility behaviour. Understanding the nature of these interactions is apparently of primary significance for gaining increased knowledge on the associations between religion and fertility.

\section{Acknowledgements}

The authors thank Alicia Adsera and two anonymous reviewers for valuable comments on earlier versions of this article. 


\section{References}

Adsera, A. 2005. "Vanishing children: from high unemployment to low fertility in developed countries." American Economic Review 95(2): 189-193.

Adsera, A. 2006a. "Marital fertility and religion in Spain, 1985 and 1999." Population Studies 60(2): 205-221.

Adsera, A. 2006b. "Religion and changes in family-size norms in developed countries." Review of Religious Research 47(3): 271-286.

Agadjanian, V. 2001. "Religion, social milieu, and the contraceptive revolution." Population Studies 55: 135-148.

Ajzen, I. 1991. "The theory of planned behaviour." Organizational Behaviour and Human Decision Processes 50: 179-211.

Argue, A., D. Johnson and L. White. 1999. "Age and religiosity: evidence from a threewave panel analysis." Journal for the Scientific Study of Religion 38(3): 423-435.

Berger, P. 1969. The sacred canopy. Elements of a sociological theory of religion, New York: Anchor Books.

Branas-Garza, P. and S. Neuman. 2006. "Is fertility related to religiosity? Evidence from Spain.” IZA Discussion Paper N. 2192, Institute for the Study of Labor (IZA).

Buehler, C. and D. Philipov. 2005. "Social capital related to fertility: theoretical foundation and empirical evidence for Bulgaria." Vienna Yearbook of Population Research. Vienna: Austrian Academy of Sciences 2005: 53-82.

Caltabiano, M., G. Dalla Zuanna and A. Rosina. 2006. "Interdependence between sexual debut and church attendance in Italy." Demographic Research 14: 453-484.

Chatters, L., R. Taylor, K. Lincoln and T. Schroepfer. 2002. "Patterns of informal support from family and church members among African Americans." Journal of Black Studies 33(1): 66-85.

Chaves, M. 1991. "Reply: Family structure and Protestant church attendance: the sociological basis of cohort and age effects." Journal for the Scientific Study of Religion 30(4): 501-514.

Clark, A. and O. Lelkes. 2005. "Deliver us from evil: religion and insurance." PSE Working Papers 2005-43, PSE (Ecole normale supérieure).

Crockett, A. and D. Voas. 2006. "Generations of decline: religious change in 20-th Century Britain.” Journal for the Scientific Study of Religion 45(4): 567-584.

Davie, G. 1990. "Believing without belonging: is this the future of religion in Britain?" Social compass 37(4): 455-469.

Davie, G. 2002. "Praying alone? Church-going in Britain and social capital: a reply to Steve Bruce." Journal of Contemporary Religion 17(3): 329-34.

Day, A. 2006. "Believing in belonging: a qualitative analysis of being Christian for the 2001 census." Paper presented at the conference: "Political demography: ethnic, national and religious dimensions" September 2006, London.

Dobbelaere, K. 1995. "Religion in Europe and North America." In: R. de Moor (ed.) Values in Western Societies, Tilburg: Tilburg University Press.

Ellison, C. and L. George. 1994. "Religious involvement, social ties, and social support in a Southeastern community." Journal for the Scientific Study of Religion 33(1): 46-61.

Frejka, T. and C. Westoff. 2006. "Religion, religiousness and fertility in the U.S. and in Europe.” MPIDR Working Paper 2006-013, Max Planck Institute for Demographic Research. 
Goldscheider, C. 1971. Population, Modernization, and Social Structure. Boston: Little, Brown and Company.

Halman, L. and V. Draulans. 2006. "How secular is Europe?" The British Journal of Sociology 57(2): 263-288.

Hamberg, E. 1991. "Stability and change in religious beliefs, practice, and attitudes: a Swedish panel study." Journal for the Scientific Study of Religion 30(1): 63-80.

Huber, S. 2003. Zentralität und Inhalt. Ein neues multidimensionales Messmodell der Religiosität. Opladen, Leske und Budrich.

Iannaccone, L. 1990. "Religious practice: a human capital approach." Journal for the Scientific Study of Religion 29(3): 297-314.

Kaufmann, E. 2006. "The end of secularisation in the West?" Paper presented at the conference: "Political demography: ethnic, national and religious dimensions" September 2006, London.

Kohler, H.-P., F. Billari and J.A. Ortega. 2002. "The emergence of lowest-low fertility in Europe during the 1990s." Population and Development Review 28(4): 641-680.

Krause, N., C. Ellison, B. Shaw, J. Marcum, and J. Boardman. 2001. "Church-based social support and religious coping." Journal for the Scientific Study of Religion 40(4): 637-656.

Lambert, Y. 2004. "A turning point in religious evolution in Europe." Journal of Contemporary Religion 19(1): 29-45.

Lehrer, E. 2004. "Religion as a determinant of economic and demographic behavior in the United States." Population and Development Review 30(4): 707-726.

Lesthaeghe, R. and J. Surkyn. 1988. "Cultural dynamics and economic theories of fertility change." Population and Development Review 14(1): 1-45.

McQuillan, K. 1999. Culture, religion and demographic behaviour. Catholics and Lutherans in Alsace, 1750-1870. McGill-Queen's University Press, Montreal and Kingston.

McQuillan, K. 2004. "When does religion influence fertility?" Population and Development Review 30(1): 25-56.

Miller, A. and T. Nakamura. 1996. "On the stability of church attendance patterns during a time of demographic change: 1965-1988." Journal for the Scientific Study of Religion 35(3): 275-284.

Mills, M. and H.-P. Blossfeld. 2005. "Globalization, uncertainty and early life course. A theoretical framework." In: Blossfeld, H.-P., E. Klijzing, M. Mills and K. Kurz, (editors) 2005: Globalization, uncertainty and youth in society, Routledge, London and New York.

Morgan, S. P. 1981. "Intention and uncertainty at later stages of childbearing: the United States 1965 and 1970.” Demography 18(3): 267-285.

Pargament, K., H. Koenig and L. Perez. 2000. "The many methods of religious coping: development and initial validation of the RCOPE." Journal of Clinical Psychology 56(4): 519-543.

Philipov, D., Z. Spéder and F.C. Billari. 2006. "Soon, later or ever? The impact of anomie and social capital on fertility intentions in Bulgaria (2002) and Hungary (2001)." Population Studies 60(3): 289-308.

Schoen, R., Y. Kim, C. Nathanson, J. Fields and N. M. Astone. 1997. "Why do Americans want children?" Population and Development Review 23(2): 333-358. 
Stark, R., E. Hamberg and A. Miller. 2005. "Exploring spirituality and unchurched religion in America, Sweden, and Japan.” Journal of Contemporary Religion 20(1): 3-23.

Stark, R. and L. Iannaccone. 1994. “A supply-size reinterpretation of the 'secularization' of Europe." Journal for the Scientific Study of Religion 33(3): 230-253.

Stolzenberg, R., M. Blair-Loy and L. Waite. 1995. "Religious participation in early adulthood: age and family life cycle effects on church membership." American Sociological Review 60(1): 84-103.

Taylor, R. and L. Chatters. 1988. "Church members as a source of informal social support." Review of Religious Research 30(2): 193-203.

Tiley, J. 2003. "Secularization and aging in Britain: does family formation cause greater religiosity?" Journal for the Scientific Study of Religion 42(2): 269-278.

Van de Kaa, D. 1999. "Europe and its population: the long view." In: Van de Kaa, D., H. Leridon, G. Gesano and M. Okólski (editors) 1999: European populations. Unity in diversity. European Studies of Population (Volume 6). Kluwer, Dordrecht: 1-49.

Voas, D. and S. Bruce. 2004. "The 2001 Census and Christian identification in Britain." Journal of Contemporary Religion 19(1): 23-28.

Voas, D. and A. Crockett. 2005. "Religion in Britain: neither believing nor belonging." Sociology 39(1): 11-28.

Waite, L. and E. Lehrer. 2003. "The benefits from marriage and religion in the United States: a comparative analysis." Population and Development Review 29(2): 255-275. 